\title{
IMPROVEMENT OF SELECTIVE COPPER EXTRACTION FROM A HEAT-TREATED CHALCOPYRITE CONCENTRATE WITH ATMOSPHERIC SULPHURIC-ACID LEACHING
}

\author{
IZBOLJŠANJE SELEKTIVNE EKSTRAKCIJE BAKRA IZ \\ TOPLOTNO OBDELANEGA KONCENTRATA HALKOPIRITA Z \\ LUŽENJEM Z ŽVEPLENO KISLINO NA ZRAKU
}

\author{
Elif Uzun', Mustafa Zengin², İsmail Atılgan'1 \\ ${ }^{1}$ Karabuk University, Department of Metallurgy and Material Science Engineering, 78050 Karabuk, Turkey \\ ${ }^{2}$ Kalimakina Company, Department of Mining, 16059 Bursa, Turkey \\ elifuzun@karabuk.edu.tr \\ Prejem rokopisa - received: 2015-05-04; sprejem za objavo - accepted for publication: 2015-05-13
}

doi:10.17222/mit.2015.091

\begin{abstract}
The present work focuses on the extraction of $\mathrm{Cu}$, suitable for production, directly from a leach solution of a chalcopyrite concentrate as an alternative to the conventional smelting and refining method. Firstly, the main aspects of the kinetics of chalcopyrite leaching in a sulphuric-acid solution and transformation reactions of chalcopyrite at high temperatures were briefly reviewed. Secondly, atmospheric-acid leaching experiments were performed as a function of the acid content and temperature under agitation. Direct leaching experiments resulted in very low and scattered $\mathrm{Cu}$ recoveries, hence revealing a sulphide passivation layer on the chalcopyrite. In order to get rid of this layer, the sulphides in the chalcopyrite were transformed into sulphates with heat treatment at $500{ }^{\circ} \mathrm{C}$ prior to the leaching process, in which a high dissolution of species was obtained. Finally, the leaching of the pre-heated concentrate resulted in a $99.82 \% \mathrm{Cu}$ extraction. Consequently, optimized process parameters were proposed by comparing the $\mathrm{Cu}$ extraction and the increased purity of the pregnant solution without Fe impurities.
\end{abstract}

Keywords: chalcopyrite concentrate, leaching, heat treatment, passivation layer, copper extraction, selectivity

Namen tega dela je ekstrakcija bakra $(\mathrm{Cu})$, ki bi bila primerna za neposredno proizvodnjo iz lužine koncentrata halkopirita, kot alternative običajni metodi s taljenjem in rafinacijo. Najprej je bil opravljen pregled glavnih vidikov kinetike izluževanja halkopirita $v$ raztopini solne kisline in reakcij pretvorbe halkopirita pri visokih temperaturah. Nato so bili izvedeni preizkusi izluževanja na zraku v kislini, v odvisnosti od vsebnosti kisline in temperature z mešanjem. Neposredni preizkusi izluževanja so pokazali zelo nizko in raztreseno pridobitev bakra, ker se je halkopirit prekril s sulfidnim pasivacijskim slojem. Da bi se tega sloja znebili, so bili sulfidi v halkopiritu pretvorjeni v sulfate, s toplotno obdelavo pri $500{ }^{\circ} \mathrm{C}$ pred postopkom izluževanja, pri katerem je bilo doseženo dobro raztapljanje vzorca. Končno je bilo doseženo 99,82 \% izluževanje bakra $(\mathrm{Cu})$ iz predogretega koncentrata. Posledično so bili predlagani optimalni parametri procesa s primerjavo ekstrakcije bakra $(\mathrm{Cu})$ in povečane čistosti nosilne raztopine brez nečistoč železa $(\mathrm{Fe})$.

Ključne besede: koncentrat halkopirita, izluževanje, toplotna obdelava, pasivacijska plast, ekstrakcija bakra, selektivnost

\section{INTRODUCTION}

Copper has been one of the most important metals for over five thousand years. ${ }^{1}$ Production of copper was easy for high-grade copper ores, for which traditional batchsmelting techniques were used before their grades were degraded. Afterwards, beneficiation of lower-grade ores was realised with the flotation technique prior to the smelting process. However, the traditional smelting technique became costly as the ore grades further decreased. On the other hand, there is currently an imbalance between the copper supply and the world demand. ${ }^{2}$ In dealing with this problem, nowadays researchers are working hard to decrease process costs.

Chalcopyrite $\left(\mathrm{CuFeS}_{2}\right)$ is one of the most abundant and widely spread copper-bearing minerals, ${ }^{3}$ accounting for approximately $70 \%$ of the Earth's copper. ${ }^{4}$

In traditional smelting processes, the chalcopyrite concentrate of a desired grade is obtained with a multi- stage flotation of a sulphide ore, having fine grains of chalcopyrite dispersed in a matrix of various sulphide minerals and quartz. ${ }^{1,4}$ The chalcopyrite concentrate is then smelted in reverberatory flash furnaces. ${ }^{5,6} \mathrm{~A}$ major problem with smelting is the pollution of the environment, especially with sulphur dioxide. ${ }^{1}$ At the same time, there is a decline in the copper-ore grades, often remarked upon as a future challenge in the production of copper for industry. ${ }^{7}$

Hydrometallurgical processes, an alternative to smelting, offer a high potential for treating chalcopyrite concentrate, apart from heap leaching, since they result in increased metal recoveries and reduced air pollution. ${ }^{4}$ In acidic media (sulfuric, hydrochloric and nitric acid), the concentrate can be leached under atmospheric or elevated pressures. ${ }^{8-14}$ Among them, the most promising one is sulfuric acid, since it can be readily produced at lower costs as the ore and, hence, the concentrate contain considerable amounts of sulphur. 
The kinetics of leaching in sulfuric-acid media have been extensively analysed as chalcopyrite can be dissolved in a strong sulfuric acid. ${ }^{15}$ The main reactions are as follows:

$$
\begin{aligned}
\mathrm{CuFeS}_{2}+2 \mathrm{H}_{2} \mathrm{SO}_{4} & \rightarrow \mathrm{CuSO}_{4}+\mathrm{FeSO}_{4}+2 \mathrm{H}_{2} \mathrm{~S} \\
\mathrm{H}_{2} \mathrm{~S}+\mathrm{H}_{2} \mathrm{SO}_{4} & \rightarrow \mathrm{S}^{0}+\mathrm{SO}_{2}+2 \mathrm{H}_{2} \mathrm{O}
\end{aligned}
$$

and

$$
2 \mathrm{FeSO}_{4}+2 \mathrm{H}_{2} \mathrm{SO}_{4} \rightarrow \mathrm{Fe}_{2}\left(\mathrm{SO}_{4}\right)_{3} \mathrm{SO}_{2}+2 \mathrm{H}_{2} \mathrm{O}
$$

These reactions are very slow at atmospheric pressure because of the formation of a sulphide passivation layer on the chalcopyrite surface during the leaching process. ${ }^{16}$ There have been many efforts at the lab scale to overcome the difficulty of the concentrate being oxidized in the presence of several species (ferric ions, cupric ions, bacteria, pyrite oxygen, etc.). ${ }^{17-22}$ Additionally, some researches have been done to increase the leach rate by favouring anodic reaction between the passivation layer and pyrite using the following redox reactions $(4,5,6): 16$

$$
\mathrm{CuFeS}_{2}+4 \mathrm{Fe}^{3+} \rightarrow \mathrm{Cu}^{2+}+5 \mathrm{Fe}^{2+}+2 \mathrm{~S}^{0}
$$

Anodic half-cell reaction: chalcopyrite oxidation

$$
\mathrm{CuFeS}_{2} \rightarrow \mathrm{Cu}^{2+}+\mathrm{Fe}^{2+}+2 \mathrm{~S}^{0}+4 \mathrm{e}^{-}
$$

Cathodic half-cell reaction: reduction of ferric ions

$$
4 \mathrm{Fe}^{3+}+4 \mathrm{e}^{-} \rightarrow 4 \mathrm{Fe}^{2+}
$$

Another process for increasing the leach rate can be roasting before leaching due to the fact that an oxidized and/or sulphatized concentrate has a higher dissolution rate because of the altered sulphide passivation layer. ${ }^{23-28}$ So, the pre-heating of chalcopyrite concentrate before the leaching in a different ambient would be an important step for the extraction of copper. As the passivation layer is composed of sulphur, it requires a sulphatization or oxidation process at elevated temperatures from $500-1000 \mathrm{~K}$ in an oxidizing ambient. Probable reactions during this treatment are extensively analysed in the literature. ${ }^{1,29}$ Among them, the most important ones for low temperatures are briefly given, in light of the relevant literature. L. Meunier et al. ${ }^{29}$ studied the behaviour of chalcopyrite in a stream of air in a lower-temperature regime of $573-8230 \mathrm{~K}$. The following reactions were mainly formed:

$$
\begin{aligned}
& 2 \mathrm{CuFeS}_{2} \rightarrow \mathrm{Cu}_{2} \mathrm{~S}+2 \mathrm{FeS}+\mathrm{S} \\
& \mathrm{FeS} \rightarrow \mathrm{Fe}_{3} \mathrm{O}_{4}+\mathrm{Fe}_{2} \mathrm{O}_{3} \\
& \mathrm{Cu}_{2} \mathrm{~S} \rightarrow \mathrm{Cu}_{2} \mathrm{O} \rightarrow \mathrm{CuSO}_{4} \rightarrow \mathrm{CuO} \cdot \mathrm{CuSO}_{4} \rightarrow \\
& \rightarrow \mathrm{CuO} \rightarrow \mathrm{CuFe}_{2} \mathrm{O}
\end{aligned}
$$

The first reaction (7) describes direct oxidation of chalcopyrite with released sulphur dioxide, occurring preferentially at temperatures higher than $900 \mathrm{~K}$. At lower temperatures, sulphides are transformed into sulphates, as shown with reactions (8), (9) and (10). In the first step, $\mathrm{Cu}$ and $\mathrm{Fe}$ are separated form chalcopyrite in the form of sulphide and elemental sulphur. And then, these sulphides are oxidized as iron sulphide can be gradually transformed to magnetite and then hematite, as given in (9); copper sulphide can be easily converted into copper sulphate at low temperatures, and sequentially into tenorite and copper iron oxide at higher temperatures, as given in (10). Here, the produced copper iron oxide is reported to have a higher intrinsic resistance to an acidic attack than tenorite. ${ }^{30}$ As a result, chalcopyrite can be transformed into sulphates and oxides, which can be dissolved in sulphuric acid in line with the following reaction:

$$
\mathrm{CuO}+\mathrm{H}_{2} \mathrm{SO}_{4} \rightarrow \mathrm{CuSO}_{4}+\mathrm{H}_{2} \mathrm{O}
$$

The main aim of this work is to improve the leaching rate of chalcopyrite concentrate in a sulphuric-acid solution under atmospheric pressure in order to have a high $\mathrm{Cu}$ recovery at a low process cost. So, only sulphuricacid solution without any catalysis was used for the leaching experiments since it can be produced from the same concentrate. In the first stage, direct leaching experiments were performed to disclose the low dissolution rate of chalcopyrite. This rate resulted in a limited extraction of $\mathrm{Cu}$ due to the existence of a sulphide layer on chalcopyrite and was, therefore, too far from establishing an industrial process. In the second stage, the concentrate was pre-heated at $500{ }^{\circ} \mathrm{C}$ to increase the extraction of $\mathrm{Cu}$ by converting sulphides into sulphates in the concentrate. In this case, the dissolution rate was found to increase enormously and a $\mathrm{Cu}$ extraction higher than $99.8 \%$ was obtained in a leaching time of $180 \mathrm{~min}$. Finally, a compromise between $\mathrm{Cu}$ and $\mathrm{Fe}$ extractions was made to have the pregnant solution free of $\mathrm{Fe}$ as much as possible.

\section{EXPERIMENTAL WORK}

\subsection{Materials, analysis and characterization of samples}

The agitated acid leaching method was used at atmospheric pressure for the $\mathrm{Cu}$ extraction from the chalcopyrite concentrate obtained from a newly discovered copper mine in the Kastamonu-Hanönü region of Turkey. The concentrate was produced by means of beneficiation of the sulphide copper ore via the flotation technique in a pilot-scale plant. In the first step, mineralogical/elemental analyses of the concentrate were obtained and summarized in Table 1. We can briefly say that the concentrate consists of $65 \%$ chalcopyrite, $30 \%$ pyrite and $5 \%$ sphalerite.

In this work, mineralogical analyses of the samples were investigated with an X-ray diffractometer (Rigaku Primus IV) and elemental analyses were carried out with an inductively coupled plasma-atomic adsorption spectrometer (ICP-OES, Perkin Elmer Optima 2100DV) and an atomic absorption spectrometer (AAS, Perkin Elmer AAnalyst 400). Additionally, a particle-distribution analysis was performed by means of an optical analysis (Nikon EPIPHOT 200); thus, the sizes of the chalcopyrite particles were found to be in the range of $1-60 \mu \mathrm{m}$ 
and $80 \%$ of the particles were below $45 \mu \mathrm{m}$. During the leaching operations, sulphuric acid with a purity of $96 \%$ and a density of $1.84 \mathrm{~g} / \mathrm{cm}^{3}$, obtained from the MERCK Company, and distilled water were used. The pre-heating and drying of the samples was done using a furnace (Protherm PL442T) and a stove (drying oven, MAS DT104), respectively. Finally, $\mathrm{Cu}$ and $\mathrm{Fe}$ extraction percentages were determined with the weighting method, using an ordinary lab scale with a $1 \mathrm{mg}$ resolution.

Table 1: Mineralogical/elemental analysis of chalcopyrite concentrate Tabela 1: Mineraloška/elementna analiza koncentrata halkopirita

\begin{tabular}{|c|c|c|c|c|c|c|}
\hline $\begin{array}{c}\text { Mineral/ } \\
\text { Element }\end{array}$ & $\mathrm{SiO}_{2}$ & $\mathrm{~S}$ & $\mathrm{Cu}$ & $\mathrm{Zn}$ & $\begin{array}{c}\mathrm{Au} \\
(\mathrm{g} / \mathrm{t})\end{array}$ & $\mathrm{Fe}$ \\
\hline$\%$ & 1.12 & 36.44 & 21.10 & 21.26 & 0.39 & 33.34 \\
\hline
\end{tabular}

\subsection{Experimental methods}

Leaching experiments were performed in an $800 \mathrm{~mL}$ pyrex reactor, using the batch method. The reactor was placed in a bath, whose temperature was controlled by a temperature controller via a thermocouple within an error of $\pm 1{ }^{\circ} \mathrm{C}$. The agitation of the leach solution was continuously maintained by an external propeller, rotated at a constant speed of $350 \mathrm{~min}^{-1}$ throughout the processes. The complete system is shown in Figure 1a. Throughout this work, a constant volume of $600 \mathrm{cc}$ of the leaching solution was used and its temperature was increased to the preselected value prior to the addition of $60 \pm 0.5 \mathrm{~g}$ of the concentrate, which maintained a constant solid-content weight-to-volume ratio $(\mathrm{w} / \mathrm{v})$ of $1 / 10$ in the solution. With the addition of the concentrate, the leaching process was commenced. After the process was finished, or a sample was taken out of the reactor, the residue was obtained using white-band filter paper. Upon determining its weight and carrying out elemental analyses, the amounts of $\mathrm{Cu}$ and $\mathrm{Fe}$ were determined and used for the calculation of the extraction percentage.

The process flowchart of this work is given in Figures $\mathbf{1 b}$ and 1c, for direct and pre-heated leaching pro-

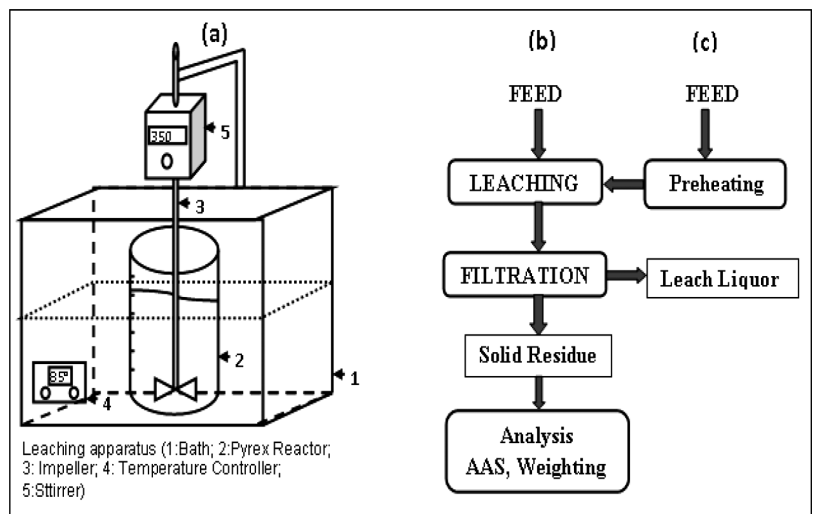

Figure 1: Experimental setup: a) flowchart of direct, b) pre-heated and c) leaching processes

Slika 1: Eksperimentalni sestav: a) potek neposrednega, b) toplotno predobdelanega in c) izluževalnega procesa cesses, respectively. Initially, direct-leaching experiments without any pre-treatment of the concentrate were performed and very low extraction percentages were obtained. Secondly, the leaching process halted at the end of every 60-min period and the pregnant solution was replaced with a fresh solution in order to see the effect of acid consumption. Finally, the concentrate was pre-heated in air ambient at $773 \mathrm{~K}$ for $2 \mathrm{~h}$ in order to achieve an alteration of sulphide minerals.

\section{RESULTS AND DISCUSSION}

\subsection{Direct atmospheric acid leaching}

Experiments of direct leaching were performed with the parameters of temperature and sulphuric-acid concentration under atmospheric pressure for $360 \mathrm{~min}$. The parameters and corresponding $\mathrm{Cu} \%$ extraction results are reported in Table 2. Although the results of the $\mathrm{Cu} \%$ extraction given in Table $\mathbf{2}$ are somehow scattered, a net increase by the temperature is observed. Thus, the effect of the acid concentration seems to be lower than that of the temperature as the temperature increases. More importantly, the $\mathrm{Cu} \%$ extraction stays below $17 \%$, which is in agreement with the results reported in the literature. ${ }^{31}$ This behaviour contradicts the one explained above, in which galvanic reactions are reported to dominate the process due to the addition of pyrite, for the redox potential to be between 400 and $500 \mathrm{mV} .{ }^{15} \mathrm{In}$ our case, as the concentrate has $30 \%$ pyrite, galvanic effects may also be expected for the reactions without any electric field. However, a probable built-in redox potential seems to stay below $400 \mathrm{mV}$, since pyrite stays undissolved. Otherwise, pyrite should be dissolved at the redox potential of $500 \mathrm{mV} .{ }^{32-33}$ Another evidence of this is the XRD analysis of the leach residue, given in Figure 2, where the pyrite and chalcopyrite peaks are clearly seen. This confirms that the dissolution processes of chalcopyrite and pyrite in sulphuric acid are very slow when there is no control of the redox potential of the leach solution.

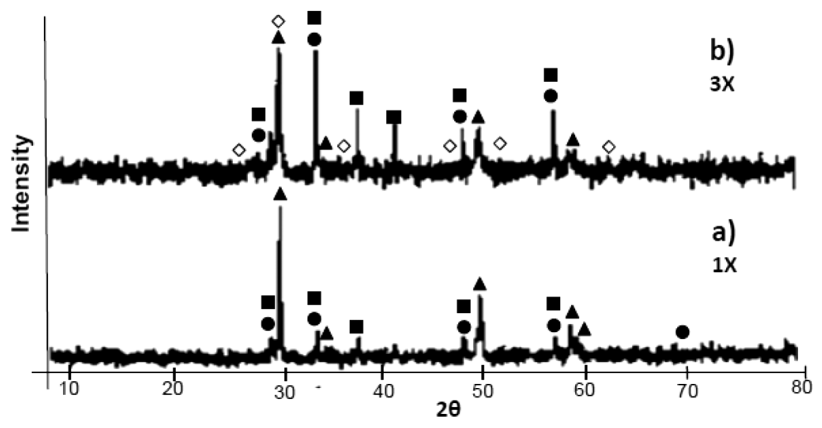

Figure 2: XRD spectra of: a) chalcopyrite concentrate and b) residue of direct leaching process with $105 \mathrm{~g}$ of acid content at $85{ }^{\circ} \mathrm{C}$ for 360 min (chalcopyrite: $\boldsymbol{\Delta}$; pyrite: $\mathbf{\square}$; sphalerite: $\bullet$; jarosite: $\diamond$ )

Slika 2: Rentgenograma: a) koncentrat halkopirita in b) ostanek neposrednega $360 \mathrm{~min}$ izluževanja pri $85^{\circ} \mathrm{C}$ in vsebnosti kisline $105 \mathrm{~g}$ (halkopirit: $\mathbf{\Delta}$; pirit: $\mathbf{\square}$; sfalerit: $\bullet$; jarozit: $\diamond$ ) 
Table 2: Results of direct-leaching experiments lasting for $360 \mathrm{~min}$ Tabela 2: Rezultati preizkusa 360 min neposrednega izluževanja

\begin{tabular}{|c|c|c|}
\hline $\begin{array}{c}\text { Temperature } \\
(\mathrm{C})\end{array}$ & $\begin{array}{c}\text { Acid concentration } \\
(\mathrm{g} / \mathrm{L})\end{array}$ & $\% \mathrm{Cu}$ extraction \\
\hline Room & 15 & 8.99 \\
Temperature & 45 & 15.83 \\
$(25)$ & 75 & 12.97 \\
\hline & 15 & 14.46 \\
45 & 45 & 12.10 \\
& 75 & 13.55 \\
\hline & 15 & 15.01 \\
& 45 & 16.42 \\
& 75 & 14.06 \\
\hline
\end{tabular}

On the other hand, an increase in the acid concentration from $45 \mathrm{~g} / \mathrm{L}$ to $75 \mathrm{~g} / \mathrm{L}$ at room temperature and 85 ${ }^{\circ} \mathrm{C}$ seems to cause a decrease in $\mathrm{Cu}$ recoveries of $2.86 \%$ and $2.36 \%$, respectively. This might be explained with the rapid formation of the sulphur layer, reported in the literature. ${ }^{6}$

\subsection{Effect of acid consuming}

The proposed reactions for the chalcopyrite leaching, given with Equations (1) to (3), are acid-consuming processes. The most proton-consuming (acid-consuming) reaction is given below:2,34

$$
\mathrm{CuFeS}_{2(\mathrm{~s})}+4 \mathrm{H}_{(\mathrm{aq})}^{+}=\mathrm{Cu}_{(\mathrm{aq})}^{+2}+\mathrm{Fe}_{(\text {(aq })}^{+2}+2 \mathrm{H}_{2} \mathrm{~S}_{(\mathrm{aq})}(11)
$$

It is hypothesized that it is governed by two steps: (i) a rapid dissolution to establish the equilibrium (11) between the soluble species at the chalcopyrite surface and the bulk solid and (ii) a rate-determining diffusion of the soluble species away from the surface.

In order to test the effect of the above reaction, the influence of the acid consumption on the copper extraction was investigated with a solid-liquid ratio of $1 / 20 \mathrm{~g} / \mathrm{L}$ in a $\mathrm{H}_{2} \mathrm{SO}_{4}$ concentration of $105 \mathrm{~g} / \mathrm{L}$ at $60{ }^{\circ} \mathrm{C}$. Before the process was started, a fresh acidic solution was prepared and held at a process temperature of $60{ }^{\circ} \mathrm{C}$. At the end of every 60-minute period of leaching, agitation was stopped for the solid species to precipitate in the leaching bath. Five minutes after the completed precipitation, $560 \mathrm{~mL}$ of the solid-free leach liquor was drained out of the reactor. At this step, a 1-mg residue was taken out of the reactor to analyse the copper content via AAS. Then, the process was continued with an addition of $560 \mathrm{ml}$ of the fresh solution of $105 \mathrm{~g} / \mathrm{L} \mathrm{H}_{2} \mathrm{SO}_{4}$ concentration into the reactor at $60{ }^{\circ} \mathrm{C}$. This procedure was repeated every $60 \mathrm{~min}$ throughout the process.

The effect of the acid consumption was tested by determining the $\mathrm{Cu}$ content of the residue for each sampling. The results are given in Table $\mathbf{3}$, where a smooth decrease in the copper grade of the leach residue from $17.70 \%$ to $17.10 \%$ is clearly seen at $60 \mathrm{~min}$ and 300 min., respectively. However, the dissolution rate of $\mathrm{Cu}$ decreases in time and may tend to stop at around $17 \%$. This blockage would be caused by the passivation layer grown on the surface of chalcopyrite minerals to resist the leaching kinetics, as reported in the literature. ${ }^{15,35}$ It may be concluded that the acid consumption has little effect on direct leaching of the chalcopyrite concentration since the results are not scattered as in the previous case.

\subsection{Atmospheric acid leaching of pre-heated chalcopy- rite concentrate}

The experiments above showed that the leaching of a chalcopyrite concentrate in a sulphuric-acid solution is hardly possible for industrial applications without an alteration of the passivation layer formed around chalcopyrite minerals.

Table 3: Copper concentration of the residue for each sampling when $560 \mathrm{~mL}$ of leach liquor was replaced with a new one

Tabela 3: Vsebnost bakra v ostanku za vsako vzorčenje, ko je bilo 560 $\mathrm{mL}$ tekočine za izluženje zamenjane $\mathrm{z}$ novo

\begin{tabular}{|c|c|c|}
\hline $\begin{array}{c}\text { Leaching time } \\
(\mathrm{min})\end{array}$ & $\begin{array}{c}\text { Added fresh } \\
\text { solution }(\mathrm{mL})\end{array}$ & $\begin{array}{c}\text { Cu \% of leach } \\
\text { residue }\end{array}$ \\
\hline 60 & 560 & 17.70 \\
\hline 120 & 560 & 17.40 \\
\hline 180 & 560 & 17.23 \\
\hline 240 & 560 & 17.10 \\
\hline 300 & 560 & 17.10 \\
\hline
\end{tabular}

Therefore, the concentrate was subjected to pre-heating at $773 \mathrm{~K}$ for $2 \mathrm{~h}$ in an atmospheric ambient before the leaching process. The change in the mineralogical property of the concentrate was determined with an XRD analysis whose spectra before and after the treatment are given in Figure 3. Dominant peaks of chalcopyrite and pyrite of the unprocessed concentrate are seen in Figure

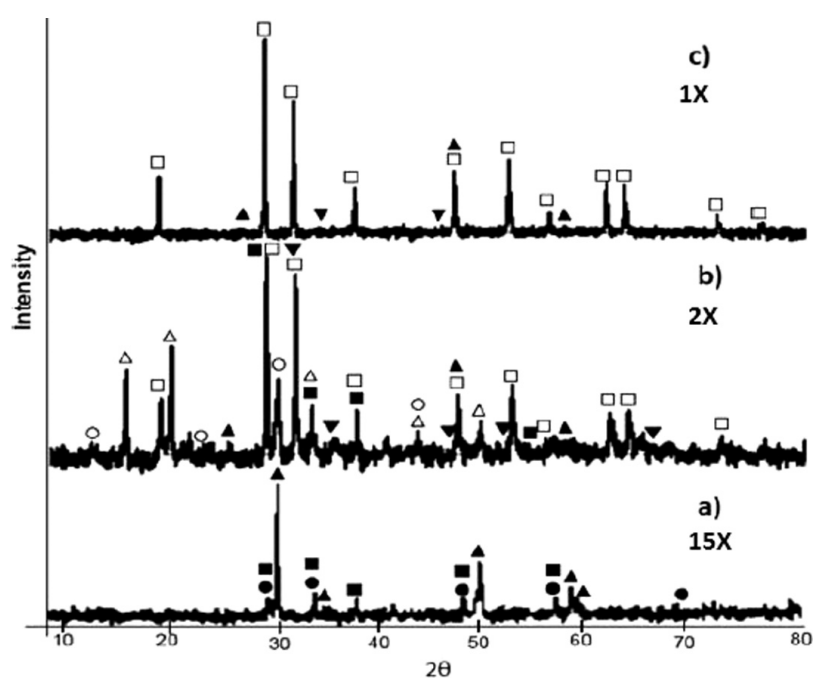

Figure 3: XRD spectra of: a) chalcopyrite concentrate, b) heated concentrate and $\mathrm{c}$ ) residue of leaching process with $150 \mathrm{~g}$ acid content at $85{ }^{\circ} \mathrm{C}$ for 360 min (chalcopyrite: $\boldsymbol{\Lambda}$; pyrite: $\mathbf{\square}$; sphalerite: $\bullet$; iron sulphate: $O$; hematite: $\square$; chalcocyanide: $\triangle$; tenorite: $\nabla$ )

Slika 3: Rentgenogrami: a) koncentrat halkopirita, b) toplotno obdelan in c) ostanka neposrednega $360 \mathrm{~min}$ izluževanja pri $85^{\circ} \mathrm{C}$, z vsebnostjo kisline $150 \mathrm{~g}$ (halkopirit: $\boldsymbol{\Delta}$; pirit: $\mathbf{\square}$; sfalerit: $\bullet$; železov sulfat: O; hematit: $\square$; halkocianit: $\triangle$; tenorit: $\mathbf{\nabla}$ ) 
3a. But, in Figure 3b, the chalcopyrite peaks are disappeared whereas the pyrite peaks are still seen for the heated concentrate; here, hematite, iron sulphate and chalcocyanide peaks appear as dominant peaks. ${ }^{36,37}$ Moreover, a trace of tenorite is found to have little peaks in Figure 3b. It can be concluded from the results that the chalcopyrite in the concentrate is almost converted to $\mathrm{CuSO}_{4}$ and $\mathrm{CuO}$, which are soluble in a sulphide-acid solution, and to those compounds (hematite and iron sulphide) resistant to an acid solution. ${ }^{1,35}$

The $\mathrm{Cu}$ and $\mathrm{Fe}$ extraction percentages in the leaching experiments of the pre-heated chalcopyrite concentrate were determined with the weighting method, via an elemental AAS analysis of the residue. The $\mathrm{Cu}$ extraction results for three different acid concentrations and temperatures as a function of the leach duration are given in Figure 4. The first thing to be mentioned is the fact that the leaching process seems to be nearly finished within $60 \mathrm{~min}$ as the lowest $\mathrm{Cu}$ extraction obtained is almost over $90 \%$ for the lowest acid content and the lowest temperature. Additionally, the time dependence on the $\mathrm{Cu}$ extraction becomes almost flat at $85{ }^{\circ} \mathrm{C}$, depicted in Figure 4, so that the reactions are nearly finished and independent of the acid concentration. Moreover, only hematite peaks are clearly observed and any trace of $\mathrm{Cu}$ bearing species is hardly found on the XRD graph given in Figure 3c, obtained for the residue of the experiment with the highest $\mathrm{Cu}$ recovery of $99.8 \%$. This enormous increase in comparison with the former experiments, obtained with the so-called direct leaching method, is

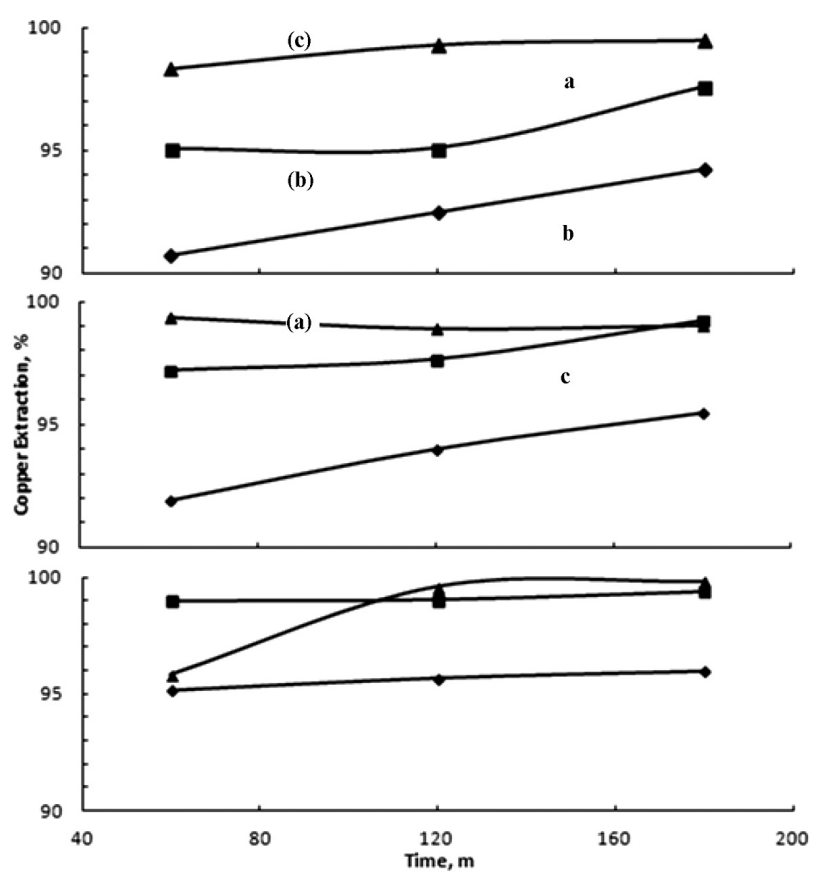

Figure 4: Copper extraction versus leaching time at: a) $90 \mathrm{~g} / \mathrm{L} \mathrm{H}_{2} \mathrm{SO}_{4}$, b) $120 \mathrm{~g} / \mathrm{L} \mathrm{H}_{2} \mathrm{SO}_{4}$, c) $150 \mathrm{~g} / \mathrm{L} \mathrm{H}_{2} \mathrm{SO}_{4}$ acid concentrations $\left(\mathbf{\square} 85^{\circ} \mathrm{C}\right.$; $\Delta 65^{\circ} \mathrm{C}$; $45^{\circ} \mathrm{C}$ )

Slika 4: Ekstrakcija bakra v odvisnosti od časa izluževanja pri koncentraciji kisline: a) $90 \mathrm{~g} / \mathrm{L} \mathrm{H}_{2} \mathrm{SO}_{4}$, b) $120 \mathrm{~g} / \mathrm{L} \mathrm{H}_{2} \mathrm{SO}_{4}$, c) $\left(\mathbf{\square} 85^{\circ} \mathrm{C}\right.$; $\Delta 65^{\circ} \mathrm{C} ; 45^{\circ} \mathrm{C}$ ) certainly caused by the alteration of the sulphides in the concentrate of the latter case.

The pre-heating of the concentrate in air ambient makes it soluble in sulphuric acid, i.e., the solubility of $\mathrm{CuSO}_{4}$ is higher than for $\mathrm{Cu}_{2} \mathrm{~S}, \mathrm{CuS}$ and $\mathrm{CuFeS}_{2}$. In addition, an increase in the solubility of hematite in a strong acid is also reported in ${ }^{38}$.

Thus, a pregnant solution may also have $\mathrm{FeSO}_{4}$ species making it hard to produce pure $\mathrm{Cu}$ directly from the solution (liquor).

Therefore, an optimization between purity and $\mathrm{Cu}$ recovery is necessary for the copper production, since Fe incorporated into the $\mathrm{Cu}$ structure especially deteriorates the electrical characteristics of copper. In other words, iron incorporation into copper should be as low as possible.

The optimization of the copper production was carried out by selecting the leaching process between the $\mathrm{Cu}$ and $\mathrm{Fe}$ recoveries, which were determined from the residue with the AAS analysis. The selectivity was calculated by subtracting $\mathrm{Fe} \%$ from the $\mathrm{Cu} \%$ recovery as a measure of the $\mathrm{Cu}$ purity in the solution, depicted in Figure 5, where $\mathrm{Cu}$ recoveries of over $97 \%$ are reported for $65^{\circ} \mathrm{C}$ and $85^{\circ} \mathrm{C}$. For example, the highest $\mathrm{Cu}$ extraction of $99.82 \%$ was obtained from the process with the parameters of the temperature, $85^{\circ} \mathrm{C}$, acid concentration, $150 \mathrm{~g} / \mathrm{L}$, and duration, $180 \mathrm{~min}$, as seen in Figure 4c; the highest Fe extraction of $37.31 \%$ was also obtained, and hence, the selectivity of the leaching process was reduced to $62.51 \%$. In the figure, the selectivity goes through a peak with the acid concentration at $65^{\circ} \mathrm{C}$, but it decreases and seems to reach saturation at $85{ }^{\circ} \mathrm{C}$. This behaviour is the evidence of an increased solubility of hematite at high acid concentrations and temperatures. As a result, the optimum leaching condition can be chosen as the peak on Figure 5, for the parameters of $65{ }^{\circ} \mathrm{C}$ and the $120 \mathrm{~g} / \mathrm{L}$ acid concentration. Weaker acid concentrations and lower temperatures seemingly result in a low $\mathrm{Cu}$ extraction, in which some $\mathrm{Cu}$ is disposed in the residue.

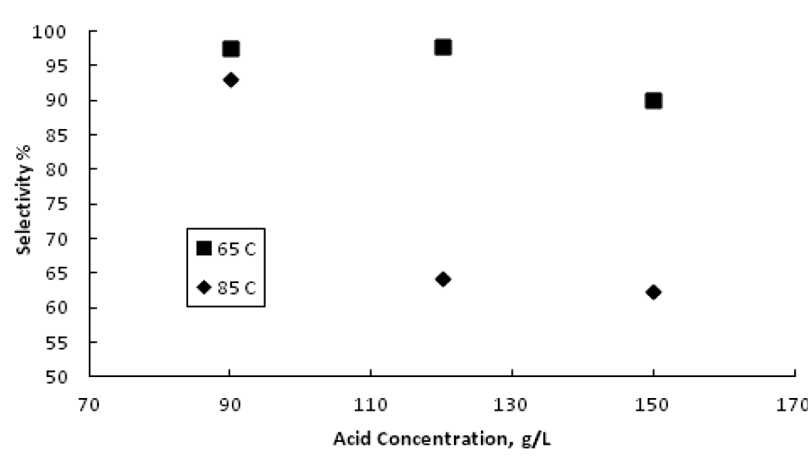

Figure 5: Selectivity of $\mathrm{Cu}$ in the solution with respect to the acid concentration for leaching processes of $180 \mathrm{~min}$

Slika 5: Selektivnost Cu v raztopini, glede na koncentracijo kisline pri trajanju izluževalnega postopka $180 \mathrm{~min}$ 


\section{CONCLUSION}

In the course of developing a hydrometallurgical process as an alternative to the conventional smelting and refining method, the production of $\mathrm{Cu}$ directly from the leach solution of the chalcopyrite concentrate would be a cornerstone. The most important step in this process is to have a Fe-free solution since Fe can be incorporated into the $\mathrm{Cu}$ structure during the subsequent electrowinning step. An observation of the selectivity between $\mathrm{Cu}$ and $\mathrm{Fe}$ can be taken as a measure of the purity of the produced copper. For achieving this aim, the main aspects of the kinetics of chalcopyrite leaching in the sulphuricacid solution is briefly reviewed in the light of the relevant literature. Additionally, transformation reactions of chalcopyrite at high temperatures are studied because direct leaching of chalcopyrite is a very slow process.

Direct-leaching experiments were performed at three different temperatures of $(25,45$ and 85$){ }^{\circ} \mathrm{C}$, and acid concentrations of $(15,45$ and 75$) \mathrm{g} / \mathrm{L}$. They resulted in very low $\mathrm{Cu}$ recoveries, below $15 \%$, due to the existence of a sulphide layer around the chalcopyrite species. In addition, a slight decrease in the acid concentration was observed at $85{ }^{\circ} \mathrm{C}$, indicating acid consumption during the process.

Acid consumption was checked with a solid-liquid ratio of $1 / 20 \mathrm{~g} / \mathrm{L}$ of a $105 \mathrm{~g} / \mathrm{L} \mathrm{H}_{2} \mathrm{SO}_{4}$ concentration at $60{ }^{\circ} \mathrm{C}$. Its effect was measured with the change in the $\mathrm{Cu}$ concentration in the leach residue over time. The $\mathrm{Cu}$ concentration was found to decrease initially and have a saturation tendency, confirming that the leaching process was limited by the motion of the species through the passivation layer around chalcopyrite.

Finally, the pre-heating of the concentrate before the leaching at $500{ }^{\circ} \mathrm{C}$ for $120 \mathrm{~min}$ was found to have converted sulphides into sulphates. The subsequent leaching experiments were performed as a function of the acid concentration in $\mathrm{g} / \mathrm{L}$, the temperature and the time, using a solid-to-liquid ratio of $1 / 10 \mathrm{w} / \mathrm{v}$ at a stirring speed of $350 \mathrm{~min}^{-1}$ under atmospheric pressure. As a result, a high dissolution rate was obtained because of the $\mathrm{Cu}$ recovery of over $90 \%$ in the leaching process of $60 \mathrm{~min}$. Thus, very high $\mathrm{Cu}$ recoveries of up to $99.82 \%$ were achieved. Besides, over $36 \%$ of $\mathrm{Fe}$ was found to have dissolved in the concentrate during the reactions because of the increased dissolution rate of hematite due to the increase in the temperature and acid concentration of the solution. Finally, the optimum selectivity of $\mathrm{Cu}$ and $\mathrm{Fe}$ was determined for the process with the acid concentration of $120 \mathrm{~g} / \mathrm{L}$, the temperature of $65^{\circ} \mathrm{C}$ and the leach duration of $180 \mathrm{~min}$. These can be taken as the proposed process parameters for the $\mathrm{Cu}$ production, optimized for the balance between the purity and $\mathrm{Cu}$ recovery.

\section{Acknowledgment}

Authors wish to thank ARGETEST Co. for experimental facilities. This work was supported by a grant from the Karabuk University BAP Project and, in part, by ASYA MADEN Co.

\section{REFERENCES}

${ }^{1}$ S. Prasad, B. D. Pandey, Alternative processes for treatment of chalcopyrite - A review, Minerals Engineering, 11 (1998) 8, 763-781, doi:10.1016/S0892-6875(98)00061-2

${ }^{2}$ H. R. Watling, Chalcopyrite hydrometallurgy at atmospheric pressure: 1 . Review of acidic sulfate, sulfate-chloride and sulfate-nitrate process options, Hydrometallurgy, 140 (2013), 163-180, doi:10.1016/j.hydromet.2013.09.013

${ }^{3}$ Y. N. Li, A. P. Kawashima, A. R. Chandra, A. Gerson, Review of the structure and fundamental mechanism and kinetics of the leaching of chalcopyrite, Adv. Coll. Int. Sci., 197-198 (2013), 1-32, doi:10.1016/j.cis.2013.03.004

${ }^{4}$ M. Loncnar, M. Zupancic, P. Bukovec, A. Toklic, The effect of water cooling on the leaching behavior of EAF slag from stainless steel production, Mater. Tehnol., 42 (2009) 6, 315-321

${ }^{5}$ A. K. Biswas, W. G. Davenpart, Extractive metallurgy of copper, 2nd Edition, Pergamon Press, New York 1974, 64-69

${ }^{6}$ Ö. Gok, G. C. Anderson, Dissolution of low-grade chalcopyrite in acidified nitride electrolyte, Hydrometallurgy, 134-135 (2013), 40-46, doi:10.1016/j.hydromet.2013.01.021

${ }^{7}$ www.indexmundi.com/en/commodities/minerals/copper/copper-t20.html

${ }^{8}$ P. B. Munoz, J. D. Miller, Wodsworth, Reaction mechanism for the acid ferric sulfate leaching of chalcopyrite, Metall. Trans. Process Metall., 103 (1979), 149-158, doi:10.1007/BF02652458

${ }^{9}$ R. Romero, A. Mazueios, I. Palencia, F. Cerranza, Copper recovery from chalcopyrite concentrates by BRISA process, Hydrometallurgy, 70 (2003), 205-215, doi:10.1016/S0304-386X(03)00081-1

${ }^{10}$ D. Dreisinger, N. Abed, A fundamental study of the reductive leaching of chalcopyrite using metallic iron, part I: kinetic analysis, Hydrometallurgy, 66 (2002), 37, doi:10.1016/S0304-386X(02) 00079-8

${ }^{11}$ F. Habashi, Action of nitric acid on chalcopyrite, Soc. Min. Eng. AIME, 254 (1973b), 224-228

${ }^{12}$ T. Hiroto, M. Kinoshito, Y. Awokira, H. Majima, The leaching of chalcopyrite with ferric chloride, Metall. Trans. B - Process Metall., 17 (1973), 19-28, doi:10.1007/BF02670815

${ }^{13}$ N. Hiroyoshi, H. Miki, T. Hirajina, M. Tsunekawa, A model for ferrous promoted chalcopyrite leaching, Hydrometallurgy, 57 (2000), 31-38, doi:10.1016/S0304-386X(00)00089-X

${ }^{14}$ N. Hiroyoshi, H. Kitagawa, M. Tsunekawa, Effect of solution composition on the optimum redox potential for chalcopyrite leaching in sulphuric acid solutions, Hydrometallurgy, 91 (2008), 144-149, doi:10.1016/j.hydromet.2007.12.005.

${ }^{15}$ J. M. S. Koleini, V. Aghazadeh, A. Sandström, Acidic sulphate leaching of chalcopyrite concantrates in presence of pyrite, Minerals Engineering, 24 (2011), 381-386, doi:10.1016/j.mineng.2010.11.008

${ }^{16} \mathrm{~T}$. R. Ingraham, R. Kerby, Roasting in extractive metallurgy - a thermodynamic and kinetic review, Can. Metall., 6 (1967) 2, 89-119, doi:10.1179/cmq.1967.6.2.89

${ }^{17}$ H. C. Linge, A study of chalcopyrite dissolution in acidic ferric nitrate by potantiometric titration, Hydrometallurgy, 2 (1976), 51-64, doi:10.1016/0304-386X(76)90013-X

${ }^{18}$ E. M. Cordoba, J. A. Munoz, M. L. Blazquaz, F. Gonzalez, A. Ballester, Passivation of chalcopyrite during its chemical leaching with ferric ion at $68{ }^{\circ} \mathrm{C}$, Minerals Engineering, 22 (2009), 229-235, doi:10.1016/j.mineng.2008.07.004 


\section{E. UZUN et al.: IMPROVEMENT OF SELECTIVE COPPER EXTRACTION FROM A HEAT-TREATED CHALCOPYRITE ...}

${ }^{19}$ D. G. Dixon, D. D. Mayne, K. G. Boxter, Galvanox - a novel galvanically assisted atmospheric leaching technology for copper concentrate, Can. Metall. Q., 47 (2008), 327-336, doi:10.1179/cmq.2008. 47.3.327

${ }^{20}$ J. E. Dutrizac, R. J. C. McDonald, T. R. Ingraham, The kinetics of dissolution of synthetic chalcopyrite in aqueous acidic ferric sulphate solutions, AIME, 245 (1969), 955-959

${ }^{21}$ R. P. Hackl, D. B. Dreisinger, E. Peters, J. A. King, Passivation of chalcopyrite during oxidative leaching in sulfate media, Hydrometallurgy, 39 (1995), 25-48, doi:10.1016/0304-386X(95)00023-A

${ }^{22}$ J. D. Miller, H. Q. Portilla, Silver catalysis in ferric sulfate leaching of chalcopyrite, In: J. Laskowski (Ed), XII International Min. Proc. Cont., Elsevier, Amsterdam 1979, 851-901

${ }^{23}$ G. Debernardi, J. C. Gentina, P. Albistur, G. Slanzi, Evaluation of processing options to avoid the passivation of chalcopyrite, International Journal of Mineral Processing, 125 (2013), 1-4, doi:10.1016/ j.minpro.2013.09.001

${ }^{24}$ C. Li, J. Li, J. Lu, X. Lu, R. Wang, X. Zhao, Bioleaching of chalcopyrite by Acidithiobacillus ferrooxidans, Minerals Engineering, 53 (2013), 184-192, doi:10.1016/j.mineng.2013.08.008

${ }^{25}$ M. Nicol, H. Miki, L. Velasquez, The dissolution of chalcopyrite in chloride solutions: Part 3, Mechanisms, Hydrometallurgy, 103 (2010), 86-95, doi:10.1016/j.hydromet.2010.03.003

${ }^{26}$ K. Kaplun, N. Li, A. Kawashima, R. Gerson, Cu and Fe chalcopyrite leach activation energies and the effect of added Fe3+, Geochimica et Cosmochimica Acta, 75 (2011), 5865-5878, doi:10.1016/j.gca. 2011.07.003

${ }^{27}$ D. Dreisinger, Copper leaching from primary sulfides: Options for biological and chemical extraction of copper, Hydrometallurgy, 83 (2006), 10-20, doi:10.1016/j.hydromet.2006.03.032

${ }^{28}$ E. Ghahremaninezhad, D. Asselin, G. Dixon, Electrochemical evaluation of the surface of chalcopyrite during dissolution in sulfuric acid solution, Electrochimica Acta, 55 (2010), 5041-5056, doi:10.1016/ j.electacta.2010.03.052
${ }^{29}$ L. Meunier, H. Vanderpoorten, Roasting reactions of chalcopyrite, ATB Met., 1 (1957), 31-35

${ }^{30}$ J. K. Gerlack, E. D. Gock, S. K. Ghosh, Activation and leaching of chalcopyrite concentrates with dilute sulfuric acid, International Symposium on Hydrometallurgy, Chicago, USA 1973, 403-416

${ }^{31}$ A. F. Tshilombo, Mechanism and kinetics of chalcopyrite passivation and depasivation during ferric and microbial leaching, $\mathrm{PhD}$ thesis, UBC, 2004

${ }^{32}$ L. M. Ou, R. A. He, Q. M. Feng, Influencing factors of pyrite leaching in germ free system, J. Cent. South Univ. Technol., 14 (2007) 1, 28-31, doi:10.1007/s11771-007-0006-3

${ }^{33}$ M. J. Nicol, I. Lazaro, The role of non-oxidative processes in the leaching of chalcopyrite, In: P. A. Riveros, D. Dixon, D. B. Dreisinger, J. Menacho, (Eds), Copper 2003-Cobre 2003, vol. VI, Canadian Institute of Mining, Metallurgy and Petroleum, Montreal 2003, 367-381

${ }^{34}$ M. Gericke, Y. Govender, A. Pinches, Tank bioleaching of low-grade chalcopyrite concentrates using redox control, Hydrometallurgy, 104 (2010), 414-419, doi:10.1016/j.hydromet.2010.02.024

${ }^{35}$ N. Li, S. Lo, C. Hu, C. Hsieh, C. Chen, Stabilization and phase transformation of $\mathrm{CuFeO} 4$ sintered from simulated copper-laden sludge, Journal of Hazardous Materials, 190 (2011), 597-603, doi:10.1016/ j.jhazmat.2011.03.089

${ }^{36}$ M. Krogovic, I. Boskovic, M. Vukcevic, R. Zejak, M. Knezevic, R. Mitrovic, B. Zlaticanin, N. Jacimovic, The influence of the mineral content of clay from the white bauxite mine on the properties of the sintered product, Mater. Tehnol., 45 (2011) 6, 609-612

${ }^{37}$ M. Vukcevic, D. Turovic, M. Krgovic, I. Boskovic, M. Ivanovic, R. Zejak, Utilization of geopolymerization for obtaining construction materials based on red mud, Mater. Tehnol., 47 (2013) 1, 99-104

${ }^{38}$ J. MacCarthy, A. Nusrati, W. Skinner, J. Addai, Dissolution and Rhedogical Behaviour of Hematite and Quartz Particles in Aqueous Media at $\mathrm{pH}$ 1, Chemical Engineering Journal, 92 (2014), 2509-2522, doi:10.1016/j.cej.2009.05.010 